
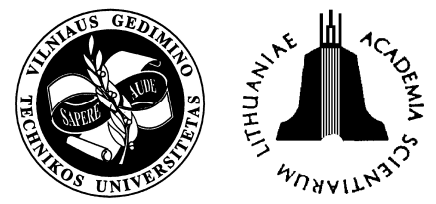

\title{
A STUDY ON THE RELATIONSHIP BETWEEN INTELLECTUAL CAPITAL AND BUSINESS PERFORMANCE IN THE ENGINEERING CONSULTING INDUSTRY: A PATH ANALYSIS
}

\author{
Chung-Fah Huang ${ }^{1}$, Sung-Lin Hsueh ${ }^{2}$ \\ ${ }^{1}$ Dept of Civil Engineering, National Kaohsiung University of Applied Sciences, No 415, \\ Chien-Kung Rd., Kaohsiung City, Taiwan.E-mail: jeffrey@cc.kuas.edu.tw \\ ${ }^{2}$ Dept of Arts and Crafts, Tung Fang Institute of Technology, No 110, Tung-Fang Rd., \\ Kaohsiung County, Taiwan.E-mail: hsueh.sl@msa.hinet.net \\ Received 13 July 2007; accepted 08 Oct 2007
}

\begin{abstract}
Engineering consulting firms, like other knowledge-based enterprises, take intellectual capital as their most important asset embedded in the organisation. This research aims to analyse the correlation between intellectual capital and business performance. The questionnaire was sent to all Taiwan's engineering consulting firms, and 101 copies were collected. It was found that, among these engineering consulting firms, the structural capital and relational capital show better performance, while human capital has poorer performance. This is especially true for staff education and training. This indicates that there is still room for improving human resource management by engineering consulting firms. It is observed by path analysis that, among the three dimensions of engineering consulting firms' intellectual capital, the human capital has a great influence on structural capital and relational capital. However, only relational capital has a direct influence on business performance. Human capital has an influence upon the business performance via the relational capital.
\end{abstract}

Keywords: engineering consulting, intellectual capital, business performance, path analysis.

\section{Introduction}

Unlike other labour-intensive companies, engineering consulting firms often provide professional knowledge and technologies, and the engineering consultants are also knowledge-based professionals. Thus the engineering consulting industry belongs to the knowledgeintensive business, for which the most important asset is intellectual capital, which is beyond the range of the balance sheet [1]. Knowledge is a close concern of engineering consulting firms, and proper management of intellectual capital might have an immediate effect on the business operation and management.

With the advent of the knowledge economy, the focus of enterprises has gradually shifted from tangible assets to intellectual capital [2]. Previous research has shown that business performance was established on intangible resources and capabilities. Drucker (1965) stressed that the most valuable asset of an enterprise was production equipment in the $20^{\text {th }}$ century, rather than knowledge workers and their productivity as in the $21^{\text {st }}$ century. Since knowledge has become the most important ingredient of modern production, how to manage properly the internal affairs of an enterprise, especially the intellectual capital, is one of the crucial subjects for business management [3].

Like other knowledge-intensive companies, the engineering consulting firms also have many intangible assets not reflected on the balance sheet. Even though it is difficult to analyse and manage knowledge of engineering consulting firms, the knowledge management activities, such as acquisition, innovation, storage, sharing and reutilisation, are closely related to enterprises' competitiveness and performance. Thus it is worthwhile to discuss if proper management of intellectual capital can improve business operation and performance.

At present there is a lack of attention devoted to study of intellectual capital in engineering consulting firms. So the questionnaire investigation in Taiwan's engineering consulting firms was conducted extensively for the purpose of: (1) understanding the acquisition and development status of intellectual capital in the engineering consulting industry; (2) exploring the influence of intellectual capital on business performance.

\section{Literature review}

\subsection{Engineering consulting industry}

As a knowledge-intensive business, the engineering consulting industry has developed into a multidisciplinary industry featuring professional and collective activities, in tune with increasingly growing complexity and demands of engineering technology. The characteristics of this industry include: 


\section{(1) High contract risk}

The principle of "trading first and then production" is observed by the contract between engineering consulting firms and clients. However, the standard of performance and the acceptance check may be affected owing to different interpretations of clauses. The long-term business operations are vulnerable to a lot of external variables, such as economic fluctuations and government policies etc.

\section{(2) Knowledge-intensive industry}

Engineering work is knowledge-intensive since the engineering design depends much upon knowledge. To solve the problems and difficulties encountered in the project, multidisciplinary know-how must be integrated to meet client requirements by achieving diversified and multifunctional projects.

\section{(3) A variety of professionals}

Engineering consulting services require support from a variety of professionals in many fields, such as civil engineers, electromechanical, computer engineers as well as accountants and lawyers. The engineering consulting staff must master abundant know-how and information technology in order to ensure project quality and safety. Meanwhile, the engineering consulting industry must keep abreast with S\&T development trends and provide value-added technical services using a fresh knowledge.

In the future, the engineering consulting industry will face fiercer competition due to lack of qualified engineers and changes in the industrial environment. Consequently, the top management must realise that a proper human resource strategy could help them meet new situations $[4,5] . \mathrm{Ng}$ and Chow [6] made separate investigations from both perspectives of clients and of engineering consulting firms, and strove to explore their different requirements with regard to consultant's performance. The results of the survey revealed that "achievement of objectives and targets", "quality of bid documents," compliance to client's requirements," "compliance to legislative requirements", and "identification of client's requirements and project objectives" were considered by both the client and consultant groups as the key consultant's performance evaluation criteria. The criteria of the design stage were generally considered more important than those of other stages. In addition, the clients and engineering consulting firms have different attitudes towards certain important factors in engineering projects. Engineering consulting firms often underestimate clients' requirements for construction period, cost, quality and security. Therefore it is crucial to maintain smooth coordination with clients in order to realise clients' engineering requirements.

\subsection{Intellectual capital}

Knowledge-intensive enterprises now attach great importance to intellectual capital, since the market value of such enterprises is far more than the value of physical assets. The so-called intellectual capital refers to the summation of all knowledge and capabilities of every employee that brings about performance and creates wealth for the enterprises. Bontis believed that knowhow, knowledge and learning capability of an enterprise cannot be defined by money, and the intellectual capital accounts for the difference between an enterprise's market value and its existing asset [7].

Roos et al [8] combined the evaluation standards of intellectual capital, described various intellectual capital frameworks and application processes by many case studies, and finally proposed a four-phase process mode and an indexing method for intellectual capital.

There are different definitions and classifications of intellectual capital due to different research backgrounds. In this paper, intellectual capital is divided into human capital, structural capital and relational capital, according to the definitions of Bontis, Hubert, Edvinsson et al $[7,9$, $10]$.

\subsection{Human capital}

According to the viewpoint of most research, human capital is an integral and most important part of intellectual capital [3, 9, 11, 12-14], including knowledge, skill, expertise of employees and managers, proactive response and entrepreneurship [8, 13].

In order to take full advantage of human capital, the top management should be well aware of the staff considerations, and provide proper training to highlight the effective utilisation of collective wisdom [15].

Grantham \& Nichols underlined the importance of 4 aspects [16]: analytical thinking, experiment, system integration and cooperation. Enterprises must not only teach the employees how to foster their professional skill through analytical thinking, but also tell them why this is important. Despite the fact that employees are the most important asset of an enterprise, the enterprises themselves are not the owner of human capital if they are not aware of the principle of resource sharing. To this end, the enterprise can strengthen and utilise properly the knowledge, skill and learning capability of employees, and also make investment in them to increase personal value and create intellectual capital for the enterprise $[3,16]$.

\subsection{Structural capital}

Structural capital is intended to share knowledge effectively, increase collective knowledge, shorten learning and preparation time and improve the productivity of human capital. It is necessary to share knowledge and experience continuously, and with the help of tools such as S\&T, manufacturing descriptions, operating manuals and Internet, utilise them repetitively and innovatively in an organised manner [3].

The structural capital contains 4 elements: system, structure, strategy and culture [9]. As these 4 elements are closely interrelated, they must be properly fitted to bring structural capital into full play, and improve the productivity of human capital through rapid knowledge-sharing, retention and well-organised procedures. 


\subsection{Relational capital}

The relational capital refers to the relationship between enterprises, customers, suppliers and partners [17], which is a key to long-lasting profit-making and successful business operation. The major considerations include customer's satisfaction, procurement frequency and time, characteristics of customers, quantity of transaction, interactions, product quality and services etc.

In this era of the information explosion, customers find it easier to find suppliers, thus enabling customers to change the balance between buyers and sellers, and improve the customers' bargaining power. Under such an environment with a fierce competition, the key to create profit and improve performance is to win the loyalty and trust of customers, and build long-term friendly relationships with them.

In an attempt to meet the challenge of competitors, engineering consulting firms must store and manage properly their intellectual capital. Since there is little relevant research for intellectual capital in engineering consulting industry, this paper has made extensive investigations on engineering consulting firms, thus providing a reference for business operation and management of intellectual capital.

\section{Research design}

\subsection{Theoretical model}

This paper intends to verify if human capital, structural capital and relational capital can improve business performance which is composed of both financial and operating performance indexes. This study also explores the correlation between 3 kinds of intellectual capital: human capital, structural capital and relational capital.

Since these capitals are complementary to each other, the intellectual capital can create value only by combining these 3 capitals [3]. The final business performance of an organisation is influenced by the interactions of the 3 dimensions of the intellectual capital. Dzinkowski, Edvinsson et al stressed that human capital was a cornerstone and influential factor in the intellectual capital $[11,13]$.
According to the literature review, human capital is believed to be the most crucial factor for intellectual capital in constructing structural capital and relational capital, which in turn, contribute to the development of human capital. Based on the aforementioned theories and with reference to the framework by Bontis [18] and Chen [19], this study established a theoretical model (Fig 1).

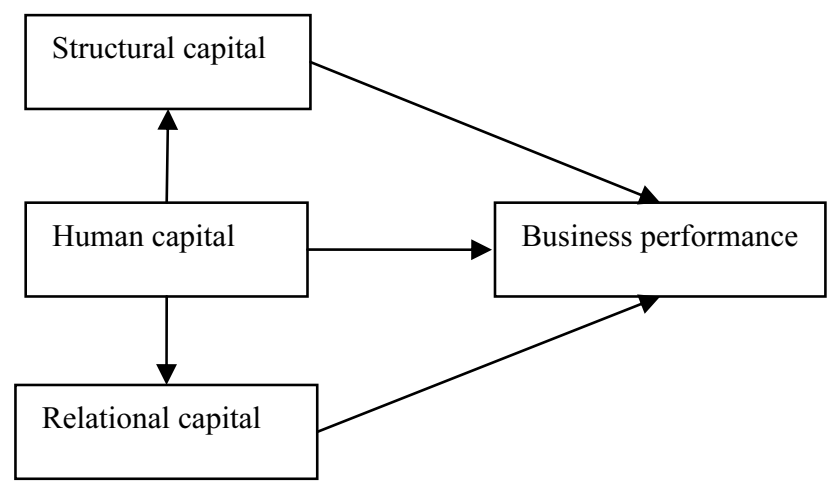

Fig 1. Theoretical model of this research

\subsection{Questionnaire design and sampling method}

As Table 1 shows, the measurement scales are divided into human capital, structural capital, relational capital, business performance, which are then subdivided into several sub-dimensions [19]. The items of these dimensions are referenced from those of past research [7, 10, 13-14, 18, 20, 21]. After questionnaire design, five managers of engineering consulting firms with over 10 -year working experience were asked to check the measurement scale, then some specific items relevant to the Taiwan's engineering consulting market were added to the scale, for example, "my company cultivates a good friendship with clients" and "my company maintains good relationships with local lawmakers". The response options were ranged by a 7-point Likert-type scale, from 1 (strongly disagree) to 7 (strongly agree), was employed to measure the response of every respondent company. For example, in relation to "my company cultivates a good friendship with clients", if "strongly disagree" is selected, a " 1 " score is obtained, if "strongly agree" is selected, a "7" score is obtained.

Table 1. Dimension, sub-dimensions and items of the measurement scale

\begin{tabular}{l|l|c}
\hline \multicolumn{1}{c|}{ Dimension } & \multicolumn{1}{|c}{ Sub-dimension } & Items in the sub-dimension \\
\hline Human capital & Staff capability & 6 \\
& Knowledge exchange among staff & 6 \\
& Staff education and training & 2 \\
\hline Structural capital & Overall business process & 5 \\
& Organisational design & 2 \\
& Information system framework & 4 \\
\hline Relational capital & Cooperation with clients & 5 \\
& Relationship with cooperative partners & 3 \\
& Cultivating a good friendship with clients & 3 \\
\hline Business performance & Financial performance index & 4 \\
& Operating performance index & 4 \\
\hline
\end{tabular}


In this study, 738 copies of the questionnaire were sent to all Taiwan's engineering consulting firms, of which 107 copies were returned, and 101 were valid. Amongst the respondents in this investigation, $70 \%$ of them were senior managers or above.

\subsection{Analytical methods}

The reliability and validity of scale were confirmed through reliability analysis. With Pearson correlation analysis, various dimensions and sub-dimensions of intellectual capital were analysed with respect to their correlation with the business performance. Then, path analysis was used to verify the theoretical model, and identify the cause-effect relationship between 3 dimensions of intellectual capital and business performance.

The correlation analysis was used to check linear relationship between variables, which constituted the basic assumptions of path analysis. So the degree of correlation is firstly confirmed through correlation analysis, and then the cause-effect relationship is confirmed through path analysis [22].

\section{Research findings}

\subsection{Sample profile}

In this study, $45.1 \%$ of the sample companies have a business history of less than 20 years, with an average of about 13 years; $50 \%$ have a staff less than 10 persons; $45 \%$ have a capital below NT\$ 5 million $(1 \mathrm{USD}=33.01$ NTD, the rate of exchange on 22 Sept 2007). Overall, the scale of Taiwan's engineering consulting firms is relatively small compared to their competitors worldwide.

\subsection{Scores of intellectual capital}

The statistical data of various dimensions of intellectual capital are listed in Table 2, wherein the mean score of human capital is 5.38 , which includes the highest mean score "staff capability" (5.51), and the lowest mean "staff education and training (4.84)". The average score of structural capital is 5.50, which includes the highest mean "information system framework" (5.70), and lowest mean "overall business process (5.35)". The average score of relational capital is 5.49 , which includes the highest mean "cooperation with clients" (5.96), and the lowest mean "cultivating a good friendship with clients (5.09)". Among the three dimensions of intellectual capital, structural capital (5.50) and relational capital (5.49) show a better performance than human capital (5.38).

The average score of business performance is only 4.54 , indicating that the firms are not satisfactory in their performance. "Operating performance (4.71)" has a higher score, and "financial performance (4.36)" has a lower score.

\subsection{Reliability analysis}

Table 2 also shows a reliability analysis of various dimensions and sub-dimensions, in which the reliability of major dimensions is higher than 0.8 , that of subdimensions is higher than 0.7 , and the overall reliability of the scale is over 0.9 , showing a high consistency and reliability of results. Overall, the scales developed in this study proved themselves to be suitable measurement tools.

\subsection{Correlation analysis}

Table 3 lists the correlation analysis results for $3 \mathrm{di}$ mensions of intellectual capital and the business performance. There is a positive correlation between 3 dimensions of intellectual capital and business performance, of which a higher positive correlation exists in human capital vs business performance and relational capital vs business performance, ie $0.439^{* *}$ and $0.418^{* *}$.

There is also a positive correlation among the 3 dimensions of intellectual capital; moreover, all coefficients exceed 0.5 , especially the coefficient of human capital and structural capital is $0.685^{* *}$, showing a remarkable level of correlation.

Table 2. Reliability and average score of various sub-dimensions in the scale

\begin{tabular}{l|l|l|l}
\hline Dimension/sub-dimension & Cronbach's $\alpha$ & Mean & S.D. \\
\hline Human capital & 0.906 & 5.38 & 0.29 \\
Staff capability & 0.787 & 5.51 & 0.75 \\
Knowledge exchange among staff & 0.862 & 5.42 & 0.87 \\
Staff education and training & 0.753 & 4.84 & 1.04 \\
\hline Structural capital & 0.900 & 5.50 & 0.32 \\
Overall business process & 0.806 & 5.35 & 0.78 \\
Organisational design & 0.728 & 5.48 & 0.91 \\
Information system framework & 0.713 & 5.70 & 0.74 \\
\hline Relational capital & 0.842 & 5.49 & 0.53 \\
Cooperation with clients & 0.803 & 5.96 & 0.61 \\
Relationship with cooperative partners & 0.785 & 5.35 & 0.87 \\
Cultivating a good friendship with clients & 0.746 & 5.09 & 0.93 \\
\hline Business performance & 0.904 & 4.54 & .334 \\
Financial performance index & 0.936 & 4.36 & 0.99 \\
Operating performance index & 0.747 & 4.71 & 0.93 \\
\hline
\end{tabular}


Table 3. Correlation matrix of measured dimensions

\begin{tabular}{l|l|l|l}
\hline & Human capital & Structural capital & Relational capital \\
\hline Human capital & 1.000 & & \\
Structural capital & $.685^{* *}$ & 1.000 & \\
Relational capital & $.506^{* *}$ & $.503^{* *}$ & 1.000 \\
Business performance & $.439^{* *}$ & $.286^{*}$ & $.418^{* *}$ \\
\hline
\end{tabular}

$* \mathrm{p}<0.05 ; * * \mathrm{p}<0.0$

Table 4. Correlation matrix of measured sub-dimensions

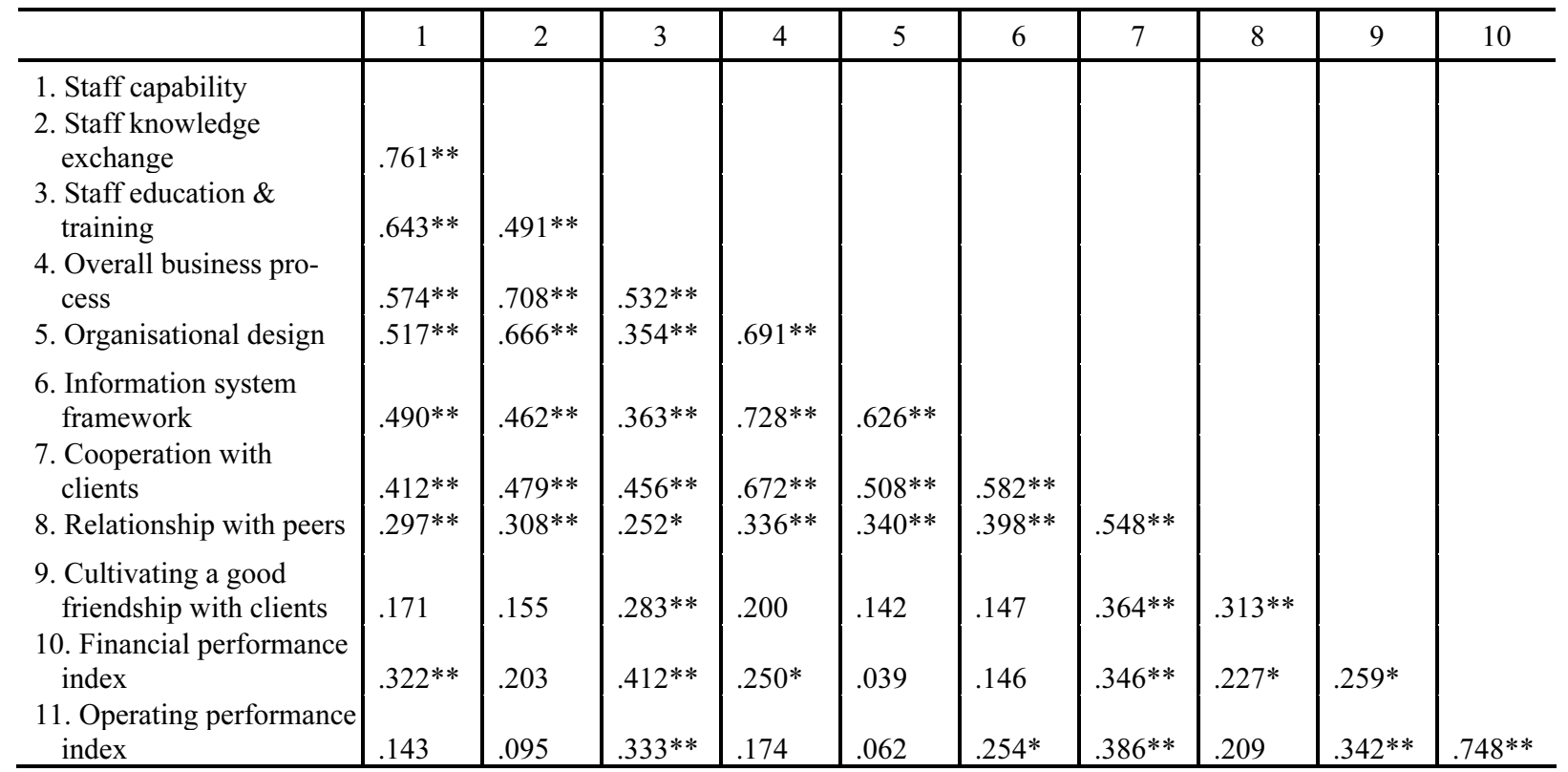

$* \mathrm{p}<0.05 ; * * \mathrm{p}<0.01$

Table 4 shows the results of correlation analysis between various sub-dimensions of intellectual capital and 2 dimensions of business performance: "financial performance" and "operating performance" indexes. There are high positive correlations between "financial performance" and "staff education and training", "staff capability" under human capital and "cooperation with clients" under relational capital, with the coefficients separately up to $0.412^{* *}, 0.322^{* *}$ and $0.346^{* *}$.

According to the correlation analysis of "operating performance" and sub-dimensions of intellectual capital, there is a high correlation between operating performance and "staff education and training" under human capital, or "cooperation with clients" and "cultivating a good friendship with clients" under relational capital, with the coefficients separately up to $0.333^{* *}, 0.386^{* *}$ and $0.342^{* *}$.

Both operating performance and financial performance are closely related to overall business performance. The correlation analysis shows that the most influential sub-dimensions for business performance include "staff education and training" under human capital and "cooperation with clients" under relational capital.

\subsection{Path analysis}

As correlation analysis cannot verify the causeeffect relationship among variables, path analysis is applied for this purpose in the theoretical model. Path analysis is a statistical method that presents and analyses the relationship among variables in a model, and it is a simplified type of structural equation modelling (SEM). The analysis method for verifying the theoretical model composed of a series of regression analysis, and all prediction variables can be proceeded in the regression model simultaneously. Thus this method is also considered to be composed of several regression equations.

The model proposed in this study is divided into 2 parts, the first part focuses on the influence of intellectual capital on business performance. The second part is about the interactions among human capital, structural capital and relational capital. These two parts are expressed by the following regression equations:

First part:

$$
Y_{1}=b_{1} X_{1}+b_{2} X_{2}+b_{3} X_{3}+\varepsilon_{1}
$$

Second part:

$$
\begin{aligned}
& Y_{2}=b_{4} X_{2}+\varepsilon_{2}, \\
& Y_{3}=b_{5} X_{2}+\varepsilon_{3},
\end{aligned}
$$

$Y_{1}$ - business performance,

$Y_{2}$ - structural capital,

$Y_{3}$ - relational capital,

$X_{1}$ - structural capital,

$X_{2}$ : - human capital,

$X_{3}$ - relational capital,

$\varepsilon_{n}-n=1 \sim 3$, error term. 
After path analysis of the theoretical model, the cause-effect relationship and path coefficients are depicted in Fig 2. It is found in the path analysis diagram that, among the 3 paths to business performance - structural capital, human capital and relational capital, only the path of relational capital to business performance is obvious, namely, only relational capital has a direct and significant influence on business performance, with a path coefficient of $0.312^{* *}$. This also proves that relational capital has a direct cause-effect relationship with business performance.

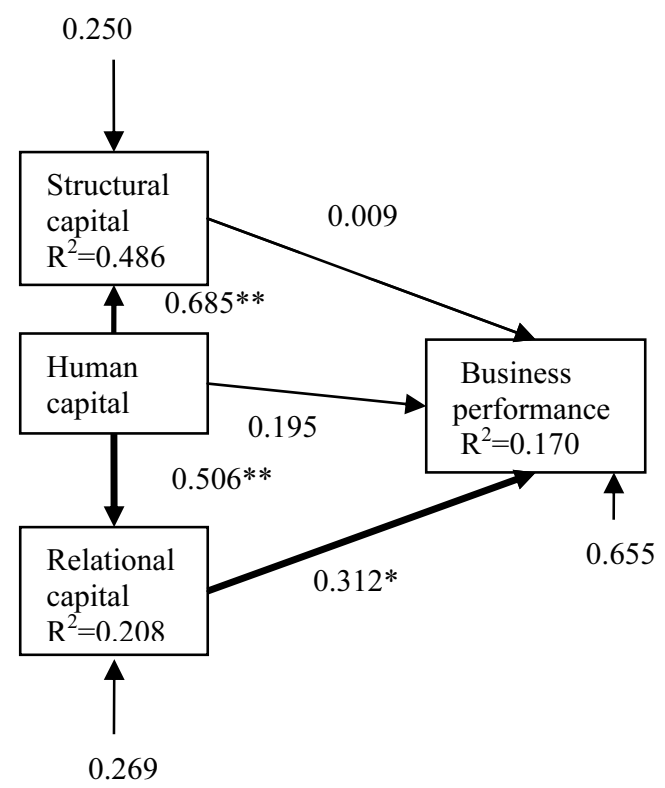

Fig 2. Path model after analysis. ${ }^{*} \mathrm{p}<0.05 ; * * \mathrm{p}<0.01$

In the second part of the model, human capital is an independent variable, while structural capital and relational capital are dependent variables with path coefficients of $0.685^{* *}$ and $0.506^{* *}$. This also proves that the human capital has immediate and considerable influence on structural capital and relational capital.

Besides, the correlation analysis shows that there is a significant positive correlation among human capital, structural capital and relational capital, indicating that human capital can positively interact with structural capital and relational capital, as illustrated in previous literature highlighting the role of human capital in intellectual capital $[3,16,19]$.

In addition to the aforementioned cause-effect relationship between the variables, human capital has indirect influence on business performance via relational capital. The overall influence is represented by the result of path coefficient analysis of human capital related to relational capital multiplied by the path coefficient of relational capital to business performance, ie $0.158(0.506 \times 0.312)$ for indirect influence effect of human capital on business performance.

\section{Conclusions}

This survey explores the performance of intellectual capital in engineering consulting firms, and finds out that structural capital and relational capital have better performance, and human capital presents the poorest performance, showing that Taiwan's engineering consulting firms give little prominence to human resource management. It is observed that there is a significant positive correlation among the 3 dimensions of intellectual capital (human, structural and relational) and business performance, and also a positive correlation among these 3 capitals.

Based on correlation analysis of 9 sub-dimensions of intellectual capital and business performance, it is learnt that "staff education and training" as well as "cooperation with clients" have an obvious relationship with business performance. But it is clearly seen from the average score of the items in the sub-dimensions that "staff education and training" in the human capital presents the poorest performance. As pointed out by Hecker: establish training and education as top priority: transform your firm into a "learning institution". Companies should encourage lifelong learners [4].

The path analysis shows that, among human capital, structural capital and relational capital of engineering consulting firms, only relational capital has a direct and significant influence on business performance, and the human capital has indirect influence on business performance via relational capital. This indicates that improving relational capital and human capital performance will directly contribute to business performance. Moreover, the human capital has a significant influence on structural capital and relational capital. The theoretical model shows 4 significant paths, ie relational capital $\rightarrow$ business performance; human capital $\rightarrow$ structural capital; human capital $\rightarrow$ relational capital; human capital $\rightarrow$ relational capital $\rightarrow$ business performance.

The empirical research shows that human capital has a significant influence on structural capital and relational capital. For this reason, the enterprises should make more investment in this area, for example, to strengthen staff education and the training system, provide subsidies for certifications and diversified incentive packages.

As for engineering consulting firms specialised in delivering knowledge services, the most valuable asset is the knowledge and experience of the staff. So, the first step is to promote the human capital and then enable it to be utilised through structural capital, eg: store systematically the business documents and records, make the employees learn necessary knowledge within the shortest time, and shorten the time for troubleshooting, encourage employees to provide knowledge and share experience with others, thus creating a knowledge-sharing enterprise culture.

\section{Acknowledgements}

Financial support from Taiwan's National Science Council is gratefully acknowledged. 
We also thank the anonymous reviewers for their valuable comments on a previous version of this manuscript.

\section{References}

1. HERREMANS, I. M.; ISAAC, R. G. The intellectual capital realization process: an application of the resourcebased view of the firm. Journal of Managerial Issues, 2004, 16(2), p. 217-231.

2. GUTHRIE, J. The management, measurement and the reporting of intellectual capital. Journal of Intellectual Capital, 2001, 2(1), p. 27-41.

3. STEWART, T. A. Intellectual capital: the new wealth of organizations. Bantam Dell Pub Group, 1999.

4. HECKER, P. A. Human resources strategies for successful consulting engineering firms. Journal of Management in Engineering, 1996, 12 (5), p. 32-36.

5. HECKER, P. A. Successful consulting engineering: a lifetime of learning. Journal of Management in Engineering, 1997, 13(6), p. 62-65.

6. NG, S. T.; CHOW, L. K. Framework for evaluating the performance of engineering consultants. Journal of Professional Issues in Engineering Education and Practice, 2004, 130(4), p. 280-288.

7. BONTIS, N. There's a price on your head: managing intellectual capital strategically. Ivey Business Quarterly, 1996, 60(4), p. 40-47.

8. ROOS, J.; KROGH, G. The epistemological challenge: managing knowledge and intellectual capital. European Management Journal, 1997, 14(4), p. 333-337.

9. HUBERT, S. O. Tacit knowledge: the key to the strategic alignment of intellectual capital. Strategy \& Leadership, 1996, 24(2), p. 10-14.

10. EDVINSSON, L.; SULLIVAN, P. Developing a model for managing intellectual capital. European Management Journal, 1996, 14(4), p. 356-364.
11. DZINKOWSKI, R. The value of intellectual capital. The Journal of Business Strategy, 2000, 21(4), p. 3-4.

12. GUTHRIE, J.; PETTY, R. Intellectual capital: Australian annual reporting practices. Journal of Intellectual Capital, 2000, 1(3), p. 241-251.

13. EDVINSSON, L. Developing intellectual capital at skandia. Long Range Planning, 1997, 30(3), p. 356-364.

14. EDVINSSON, L. Some perspectives on intangibles and intellectual capital 2000. Journal of Intellectual Capital, 2000, 1(1), p. 12-16.

15. WATSON, J. Managing intellectual capital: making the most of the best. The Canadian Manager, 1996, 21(3), p. 11-14.

16. GRANTHAM, C. E.; NICHOLS, L. D. A framework for the management of intellectual capital in the health care industry. Journal of Health Care Finance, 1997, 23(3), p. $1-19$.

17. JOHNSON, W. H. A. An integrative taxonomy of intellectual capital: measuring the stock and flow of intellectual capital components in the firm. International Journal of Technology Management, 1999, 18, p. 562-575.

18. BONTIS, N. Intellectual capital: an exploratory study that develops measures and models. Management Decision, 1998, 36(2), p. 63-76.

19. CHEN, M. C. The effect of information technology investment and intellectual capital on business performance. $\mathrm{PhD}$ thesis, National Central University. Jhongli City Taiwan, 2001.

20. BUREN, M. E. V. A yardstick for knowledge management. Training \& Development, 1999, 53(5), p. 71-78.

21. SULLIVAN, P. H. Value-driven intellectual capital: how to convert intangible corporate assets into market value. New York: John Wiley \& Sons, Inc., 2000.

22. BROWN, A. W.; ADAMS, J. D.; AMJAD, A. A. The relationship between human capital and time performance in project management: a path analysis. International Journal of Project Management, 2007, 25, p. 77-89.

\section{INTELEKTINIO KAPITALO IR VERSLO VYKDYMO KONSULTACINĖJE INŽINERIJOS PRAMONĖJE SANTYKIS: DAUGIAFAKTORINE் REGRESINE் ANALIZE்}

\section{C.-F. Huang, S.-L. Hsueh}

Santrauka

Inžinerinės konsultacinès įmonès, kaip ir kitos žiniomis grịstos organizacijos, intelektinị kapitalą laiko svarbiausiu turtu. Šio tyrimo tikslas yra nustatyti intelektinio kapitalo ir verslo vykdymo koreliaciją. Anketa buvo išsiųsta visoms Taivano inžinerinėms konsultacinèms i̇monėms, atsake 101 respondentas. Buvo nustatyta, kad struktūrinis ir santykinis šių inžinerinių konsultacinių imonių kapitalas parode geresnių rezultatų nei žmogiškasis kapitalas. Ši tiesa atsispindi ugdant darbuotojus ir juos mokant. Tai parodo, kad inžinerinèse konsultacinėse imonèse vis dar galima gerinti žmogiškuju išteklių valdymą. Iš atliktos daugiafaktorinès regresinès analizès buvo matyti, kad tarp inžinerinių konsultacinių įmonių intelektinis ir žmogiškasis kapitalas turi didelę ittaką struktūriniam ir santykiniam kapitalui. Tačiau tik santykinis kapitalas turi tiesiogini poveikị verslui. Žmogiškasis kapitalas daro poveikị verslo vykdymui per santykinị kapitalą.

Reikšminiai žodžiai: inžinerinè konsultacija, intelektinis kapitalas, verslo vykdymas, daugiafaktorinè regresinè analizė.

Chung-Fah HUANG. Assistant Professor at Dept of Civil Engineering of National Kaohsiung University of Applied Sciences, Taiwan. He majors in construction management, his research interests include human resource management in construction industry, engineering ethics and outsourcing management.

Sung-Lin HSUEH earned his PhD degree at Dept of Architecture in National Taiwan University of Science and Technology in 2006. Currently he is an Assistant Professor at Dept of Arts and Crafts in Tung Fang Institute of Technology. Concurrently he is the Managing Director of SIN-YA International Engineering Consultants Inc (Taiwan) engaged in developing real estate on the Chinese market. 